\title{
Front Matter: Volume 7959
}

, "Front Matter: Volume 7959," Proc. SPIE 7959, Optical Metro Networks and Short-Haul Systems III, 795901 (24 January 2011); doi: 10.1117/12.888709

SPIE. Event: SPIE OPTO, 2011, San Francisco, California, United States 


\title{
PROCEEDINGS OF SPIE
}

\section{Optical Metro Networks and Short-Haul Systems III}

\author{
Werner Weiershausen \\ Benjamin Dingel \\ Achyut Kumar Dutta \\ Atul K. Srivastava \\ Editors
}

25-27 January 2011

San Francisco, California, United States

Sponsored and Published by

SPIE 
The papers included in this volume were part of the technical conference cited on the cover and title page. Papers were selected and subject to review by the editors and conference program committee. Some conference presentations may not be available for publication. The papers published in these proceedings reflect the work and thoughts of the authors and are published herein as submitted. The publisher is not responsible for the validity of the information or for any outcomes resulting from reliance thereon.

Please use the following format to cite material from this book:

Author(s), "Title of Paper," in Optical Metro Networks and Short-Haul Systems III, edited by Werner Weiershausen, Benjamin Dingel, Achyut Kumar Dutta, Atul K. Srivastava, Proceedings of SPIE Vol. 7959 (SPIE, Bellingham, WA, 2011) Article CID Number.

ISSN 0277-786X

ISBN 9780819484963

Published by

SPIE

P.O. Box 10, Bellingham, Washington 98227-0010 USA

Telephone +1 3606763290 (Pacific Time) · Fax +1 3606471445

SPIE.org

Copyright (C) 2011, Society of Photo-Optical Instrumentation Engineers

Copying of material in this book for internal or personal use, or for the internal or personal use of specific clients, beyond the fair use provisions granted by the U.S. Copyright Law is authorized by SPIE subject to payment of copying fees. The Transactional Reporting Service base fee for this volume is $\$ 18.00$ per article (or portion thereof), which should be paid directly to the Copyright Clearance Center (CCC), 222 Rosewood Drive, Danvers, MA 01923. Payment may also be made electronically through CCC Online at copyright.com. Other copying for republication, resale, advertising or promotion, or any form of systematic or multiple reproduction of any material in this book is prohibited except with permission in writing from the publisher. The CCC fee code is 0277-786X/11/ \$18.00.

Printed in the United States of America.

Publication of record for individual papers is online in the SPIE Digital Library.

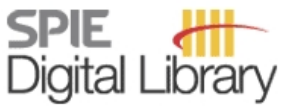

SPIEDigitalLibrary.org

Paper Numbering: Proceedings of SPIE follow an e-First publication model, with papers published first online and then in print and on CD-ROM. Papers are published as they are submitted and meet publication criteria. A unique, consistent, permanent citation identifier (CID) number is assigned to each article at the time of the first publication. Utilization of CIDs allows articles to be fully citable as soon they are published online, and connects the same identifier to all online, print, and electronic versions of the publication. SPIE uses a six-digit CID article numbering system in which:

- The first four digits correspond to the SPIE volume number.

- The last two digits indicate publication order within the volume using a Base 36 numbering system employing both numerals and letters. These two-number sets start with 00, 01, 02, 03, 04, $05,06,07,08,09,0 A, 0 B \ldots 0 Z$, followed by 10-1Z, 20-2Z, etc.

The CID number appears on each page of the manuscript. The complete citation is used on the first page, and an abbreviated version on subsequent pages. Numbers in the index correspond to the last two digits of the six-digit CID number. 


\section{Contents}

vii Conference Committee

ix Introduction

xi Photonic devices for next-generation broadband fiber access networks (Plenary Paper) [7958-01]

L. G. Kazovsky, S.-H. Yen, S.-W. Wong, Stanford Univ. (United States)

xvii Advances in coherent detection algorithms (Plenary Paper) [7960-01]

J. C. Rasmussen, T. Hoshida, T. Tanimura, H. Nakashima, S. Oda, Fujitsu Labs. Ltd. (Japan);

Z. Tao, L. Li, Fujitsu R\&D Ctr. (China)

\section{OPTICAL COMMUNICATIONS PLENARY SESSION}

795902 Higher-order modulation formats for spectral-efficient high-speed metro systems (Plenary Paper) [7959-01]

R. Freund, M. Nölle, M. Seimetz, J. Hilt, J. Fischer, R. Ludwig, C. Schubert, H.-G. Bach,

K.-O. Velthaus, M. Schell, Fraunhofer Institute for Telecommunications, Heinrich-Hertz-Institut (Germany)

OFDM FOR ACCESS, METRO AND COHERENT COMMUNICATIONS: JOINT SESSION WITH CONFERENCE 7960

795903 Four-dimensional coded optical OFDM for ultra-high-speed metro networks (Invited Paper) [7959-02]

I. B. Djordjevic, The Univ. of Arizona (United States)

795904 Optimum signal constellations for high-speed optical metro networks and beyond [7959-03] J. Zhang, Beijing Jiaotong Univ. (China); I. B. Djordjevic, The Univ. of Arizona (United States)

795905 Potential of OFDM for next generation optical access (Invited Paper) [7959-04]

D. Fritzsche, European Ctr. for Information and Communication Technologies (Germany);

E. Weis, D. Brever, Deutsche Telekom AG (Germany)

COMPONENT TECHNOLOGIES FOR ACCESS, METRO AND COHERENT COMMUNICATIONS: JOINT SESSION WITH CONFERENCES 7958 AND 7960

795906 Novel multicolor photodetectors for short- and long-distance optical communication (Invited Paper) [7959-05]

A. K. Dutta, R. Olah, G. Mizuno, Banpil Photonics, Inc. (United States); N. K. Dhar, Defense Advanced Research Projects Agency (United States) 
795908 Tuneable VCSEL aiming for the application in interconnects and short haul systems (Invited Paper) [7959-07]

C. Gierl, K. Zogal, S. Jatta, H. A. Davani, F. Küppers, P. Meissner, Technische Univ. Darmstadt (Germany); T. Gründl, C. Grasse, M.-C. Amann, Walter Schottky Institut (Germany); A. Daly, B. Corbett, Tyndall National Institute (Ireland); B. Kögel, Å. Haglund, J. Gustavsson, P. Westbergh, A. Larsson, Chalmers Univ. of Technology (Sweden); P. Debernardi, Istituto di Elettronica e di Ingegneria dell'Informazione e delle Telecomunicazioni (Italy); M. Ortsiefer, VERTILAS GmbH (Germany)

795909 Inexpensive 3dB coupler for POF communication by injection-molding production [7959-08] M. Haupt, U. H. P. Fischer, Harz Univ. of Applied Sciences (Germany)

ADVANCED PON FOR ACCESS AND METRO: JOINT SESSION WITH CONFERENCE 7958

7959 0A New concept for a regenerative amplifier for passive optical networks (Invited Paper) [7959-09]

A. Tervonen, M. Mattila, Luxdyne, Ltd. (Finland) and Aalto Univ. (Finland); W. Weiershausen, Luxdyne, Ltd. (Finland); T. von Lerber, Luxdyne, Ltd. (Finland) and Darmstadt Univ. of Technology (Germany); E. Parsons, H. Chaouch, College of Optical Sciences, The Univ. of Arizona (United States); F. Kueppers, College of Optical Sciences, The Univ. of Arizona (United States) and Darmstadt Univ. of Technology (Germany); S. Honkanen, Aalto Univ. (Finland)

\section{HIGH CAPACITY TRANSMISSION}

7959 OB Field trials of 100G and beyond: an operator's point of view (Invited Paper) [7959-10] S. Vorbeck, M. Schneiders, W. Weiershausen, H. Mayer, A. Schippel, P. Wagner, A. Ehrhardt, Deutsche Telekom AG (Germany); R. Braun, D. Brever, Deutsche Telekom Labs. (Germany); U. Drafz, Deutsche Telekom AG (Germany); D. Fritzsche, EICT GmbH (Germany)

7959 OC Scaling 100G QPSK links for reliable network development [7959-11] A. Stark, Y.-T. Hsueh, S. Searcy, T. Detwiler, Georgia Institute of Technology (United States); S. Tibuleac, M. Filer, ADVA Optical Networking (United States); G. Chang, S. E. Ralph, Georgia Institute of Technology (United States)

7959 OD Chromatic dispersion analysis and partially compensation for tunable liquid crystal optical interleaver [7959-12]

S. A. Alboon, Yarmouk Univ. (Jordan); A. S. Abu-Abed, Univ. of Central Oklahoma (United States); A. N. Al-Omari, Yarmouk Univ. (Jordan)

7959 OE Electrical PMD equalization methods for intensity modulated optical polarization multiplex transmission systems [7959-13]

D. Goelz, F. Pohl, P. Meissner, Technische Univ. Darmstadt (Germany)

7959 OF DPSK receiver-sensitivity enhancement using an SOA in front of the receiver [7959-14]

E. Awad, Nile Univ. (Egypt) 
7959 OG WSS technology for the next generation ROADM networks (Invited Paper) [7959-15]

G. Cohen, K. Bala, Oclaro, Inc. (United States)

$7959 \mathrm{OH}$ Spectrum variable colorless, directionless and contentionless multi-degree ROADM node [7959-16]

P. N. Ji, NEC Labs. America, Inc. (United States); Y. Aono, NEC Corp. (Japan); T. Wang, NEC Labs. America, Inc. (United States)

7959 Ol PCE-based scalable dynamic path control for large-scale photonic networks [7959-17]

S. Araki, NEC Corp. (Japan) and Nagoya Univ. (Japan); K. Shimada, H. Hasegawa, K. Sato, Nagoya Univ. (Japan); Y. lizawa, S. Ishida, I. Nishioka, NEC Corp. (Japan)

7959 0J Linear formulation to avoid adjacent channel interference in LTD of optical networks [7959-18]

K. D. R. Assis, Federal Univ. of Bahia (Brazil); M. S. Savasini, State Univ. of Campinas (Brazil);

A. F. Santos, Univ. of São Paulo (Brazil) and State Univ. of Southwest Bahia (Brazil)

\section{OPTICAL NETWORKS II}

7959 OK Efficient elastic optical path network for transmission beyond 100G (Invited Paper) [7959-19] B. Kozicki, H. Takara, K. Yonenaga, M. Jinno, NTT Corp. (Japan)

$7959 \mathrm{OL}$ Multi-layer photonics modeling framework for the design, analysis, and optimization of devices, links, and networks (Invited Paper) [7959-20]

A. Richter, H. Louchet, C. Arellano, VPIsystems (Germany); J. Farina, VPIsystems (United States); I. Koltchanov, VPIsystems (Germany)

7959 OM Dynamic routing, wavelength assignment, and spectrum allocation in transparent flexible optical WDM networks [7959-21]

A. N. Patel, NEC Labs. America, Inc. (United States) and The Univ. of Texas at Dallas (United States); P. N. Ji, NEC Labs. America, Inc. (United States); J. P. Jue, The Univ. of Texas at Dallas (United States); T. Wang, NEC Labs. America, Inc. (United States)

\section{POSTER SESSION}

7959 OP A novel approach to smart grid technology for electrical power transmission lines by a self-organized optical network node based on optical bistability [7959-22]

S. Nakanishi, W. Sasaki, Doshisha Univ. (Japan) 
Downloaded From: https://www.spiedigitallibrary.org/conference-proceedings-of-spie on 26 Apr 2023

Terms of Use: https://www.spiedigitallibrary.org/terms-of-use 


\title{
Conference Committee
}

\author{
Symposium Chair
}

Liang-Chy Chien, Kent State University (United States)

Symposium Cochairs

E. Fred Schubert, Rensselaer Polytechnic Institute (United States)

Klaus P. Streubel, OSRAM GmbH (Germany)

Program Track Chair

Benjamin Dingel, Nasfine Photonics, Inc. (United States)

\section{Conference Chairs}

Werner Weiershausen, Deutsche Telekom AG (Germany)

Benjamin Dingel, Nasfine Photonics, Inc. (United States)

Achyut Kumar Dutta, Banpil Photonics, Inc. (United States)

Atul K. Srivastava, OneTerabit (United States)

Program Committee

Ronald Freund, Fraunhofer-Institut für Nachrichtentechnik Heinrich-Hertz-Institut (Germany)

Akimasa Kaneko, NEL America, Inc. (United States)

Franko Küppers, College of Optical Sciences, The University of Arizona (United States)

Ralph Leppla, Deutsche Telekom AG (Germany)

Ernst-Dieter Schmidt, Nokia Siemens Networks (Germany)

Sascha Vorbeck, Deutsche Telekom AG (Germany)

Winston I. Way, Vello Systems (United States)

Session Chairs

Optical Communications Plenary Session

Benjamin Dingel, Nasfine Photonics, Inc. (United States)

Werner Weiershausen, Deutsche Telekom AG (Germany)

1 OFDM for Access, Metro and Coherent Communications: Joint Session with Conference 7960

Atul K. Srivastava, OneTerabit (United States)

Guifang Li, CREOL, The College of Optics and Photonics, University of Central Florida (United States) 
2 Component Technologies for Access, Metro and Coherent Communications: Joint Session with Conferences 7958 and 7960

Dieter Stefan Jäger, Univ. Duisburg-Essen (Germany)

Werner Weiershausen, Deutsche Telekom AG (Germany)

3 Advanced Components and Sub-Systems

Achyut K. Dutta, Banpil Photonics, Inc. (United States)

4 Advanced PON for Access and Metro: Joint Session with Conference 7958

Raj Jain, Washington University in St. Louis (United States)

Benjamin Dingel, Nasfine Photonics, Inc. (United States)

$5 \quad$ High Capacity Transmission

Atul K. Srivastava, OneTerabit (United States)

$6 \quad$ Optical Networks I: Joint Session with Conferences 7958 and 7960

Werner Weiershausen, Deutsche Telekom AG (Germany)

7 Optical Networks II

Werner Weiershausen, Deutsche Telekom AG (Germany) 


\section{Introduction}

The Optical Metro Networks and Short-Haul Systems III conference provides a forum for more than 20 papers in eight oral sessions including one plenary session, three special joint sessions, and a poster session. The joint sessions with Broadband Access Communication Technologies V (conference 7958) and Coherent Optical Communication: Components, Subsystems, and Systems (conference 7960) are designed to bring together the researchers working on topics from the adjoining fields in order to stimulate more comprehensive discussion.

The conference provides a good opportunity to learn about the current trends in the optical component, transmission and networking technologies for the metro and short haul systems. It covers components such as novel couplers, VCSELs, multi-color photo-detectors, liquid crystal dispersion compensators and SOAs for regeneration and receiver sensitivity enhancement of a DPSK system. It is evident from the submissions this year that the long haul transmission technologies such as OFDM and novel modulation formats are being explored for applications in the short reach systems. Likewise, several results of high data rate transmission and field trials at $100 \mathrm{G}$ and beyond from carrier's perspective are included in the conference. These cover the issues pertaining to PMD and the proposed introduction of channels at $400 \mathrm{~Gb} / \mathrm{s}$ and $1 \mathrm{~Tb} / \mathrm{s}$ which would require bandwidth allocation larger than $50 \mathrm{GHz}$ with a granularity of $25 \mathrm{GHz}$ or $12.5 \mathrm{GHz}$ for minimizing wasted or stranded bandwidth.

In recent years, we have witnessed the ROADM technology evolution towards larger number of ports. Colorless, directionless and contentionless routing of channels at ROADM nodes is becoming an industry standard. More recently, a new feature of bandwidth flexibility has been added to the ROADM requirements in order to support the future need of flexibility in bandwidth allocation in an efficient manner. The conference includes many papers on the design of flexible bandwidth ROADMs and related component technologies.

Several papers provide modeling results on optical network architecture and control including the multilayer photonic control. One paper highlights a novel smart grid approach to transmit electrical power via an optical network node.

We would like to thank all the contributors to this year's Optical Metro Networks and Short-Haul Systems III conference. The papers are of high quality and will provide an opportunity to review the latest results and have discussion on the 
current issues. If you were not able to attend the conference you can review the papers in this publication and hopefully contribute to the conference in the future.

\section{Werner Weiershausen Benjamin Dingel Achyut Kumar Dutta} Atul K. Srivastava 